\title{
Diaza-crown Ethers. I. Alkali Ion Promoted Formation of Diaza-crown Ethers and Syntheses of Some $N, N^{\prime}$-Disubstituted
}

\section{Derivatives}

\author{
S. KULSTAD * and L. Å. MALMSTEN
}

Division of Organic Chemistry 1 and Division of Physical Chemistry 1, Chemical Center, University of Lund, P.0. Box 740, S-220 07 Lund 7, Sweden

Macrocyclic diazaoligoethers have been prepared in relatively good yields from acyclic diiodoethers and diaminoethers at normal concentrations with template ions present.

The amines and the iodides were prepared from the corresponding dichloroethers, the former via the azides and reduction with hydrogen sulfide and the latter through substitution with iodide ion.

1,7,10,16-Tetraoxa-4,13-diazacyclooctadecane was reacted with ethylene oxide, methoxyethyl $p$-toluenesulfonate, chloroacetamide and ethyl chloroacetate, respectively, to give disubstituted diaza-crown ethers. The bis (amino acid) was obtained by hydrolysis of the corresponding diester.

A toxicity test of some of the diaza-crown ethers shows that the lethal dose is $5-50 \mathrm{mg} / \mathrm{kg}$ (mouse, i.v.).

Crown ethers, the common name for macrocyclic oligoethers, have been extensively studied ever since Pedersen in 1967 first reported the metal ion promoted formation of such compounds. 1 The closely related cryptands, which are macrobicyclic or macrotricyclic oligoethers with nitrogen atoms as bridgeheads, were synthesized by Lehn et al. using high dilution technique 2,3 and have also been given a great deal of attention. The main reason for the great interest in these compounds is their ability to selectively form complexes with certain metal ions, espe. cially the alkali and alkaline-earth cations.4,5 This property suggests many future applications for crown ethers and cryptands, e.g., as model systems in biological studies. This is emphasized

* To whom inquiries should be addressed. in "host-guest chemistry", a new branch of crown ether chemistry developed by Cram et al., in which optically active crown ethers distinguish the $(+)$ - and $(-)$-forms of $\alpha$-amino acids via complex formation. ${ }^{7}$ Several reviews have appeared, dealing with syntheses of crown ethers, complex formation with metal ions and present and future applications. ${ }^{8-11}$

Lately there has been a growing interest in heavy metal complexes of cryptands and diazacrown ethers. ${ }^{12,13}$ This class of compounds offers a unique possibility to create a specific ligand for a certain heavy metal cation with the aid of cavity size and the presence of hetero atoms in the ring. Macrocycles with side-chains containing groups with specific complexing abilities would also be of great interest, but so far very little has been published in this area. ${ }^{14}$ Therefore we decided to synthesize some disubstituted diaza-crown ethers in order to investigate their complexing behavior toward heavy metal cations.

Diaza-crown ethers have previously been obtained by using the high dilution technique ${ }^{2,3}$ or in template syntheses using the $p$-toluenesulfonamide group as the nucleophile. ${ }^{15,16}$ To avoid complicated experimental procedures and multi-step schemes, we have developed a more direct synthesis, based on the template effect.

\section{RESULTS AND DISCUSSION}

Acyclic compounds. In crown ether syntheses the most common leaving groups in the ring. closure reactions have been chlorine and 
$p$-toluenesulfonyl. ${ }^{17}$ For our purposes, the chlorides $1 a-b$ react very slowly with the amines $4 a-b$ to give the desired macrocyclic compounds, but the iodides $2 a-b$ react fast enough. The iodo derivatives also give higher yields than the corresponding tosylates, ${ }^{18}$ and are easily obtained in high yields by the Finkelstein reaction (Scheme 1). ${ }^{19}$

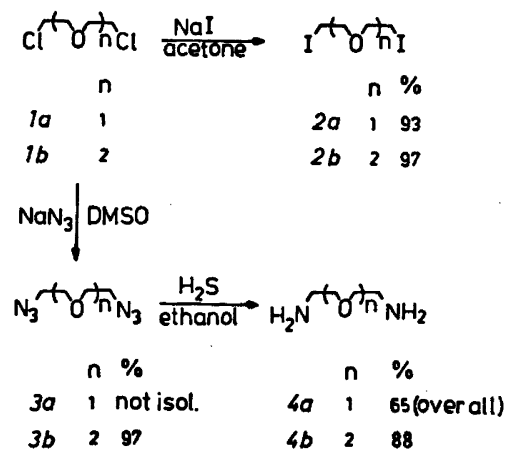

Scheme 1.

In the reports of Lehn et al.,2 the diamines $4 a-b$ were obtained by the Gabriel synthesis. ${ }^{20}$ However, the yields were only moderate and since the method is rather laborious other ways were sought. The chlorides $1 a-b$ react quantitatively with sodium azide in dimethylsulfoxide (DMSO) to give the corresponding azides $2 a-b$. The syntheses of these compounds in dimethylformamide (DMF) have previously been described. ${ }^{21}$ There are several methods for converting azido derivatives to amines, ${ }^{22}$ and we chose a seldom-used reducing agent, ${ }^{23}$ hydrogen sulfide in ethanol, which was very convenient to handle and gave good yields (Scheme 1). The reaction is base catalyzed and is initiated by the addition of triethylamine and accelerated by the amine formed.

Ring-closure reaction. The macrocyclic com. pounds $5 a-c$ have been synthesized by Lehn et al..$^{3}$ using the high dilution technique. Since this method requires precision dropping funnels, very dry solvents, large volumes etc., we developed a method based on the template effect, described by many authors..,16,24,25 The most common nucleophiles in these reports have been negatively charged alkoxy or amido groups, ${ }^{22}$ but in the syntheses of monoaza-crown ethers ${ }^{26}$ the neutral amino group has ulso been used.

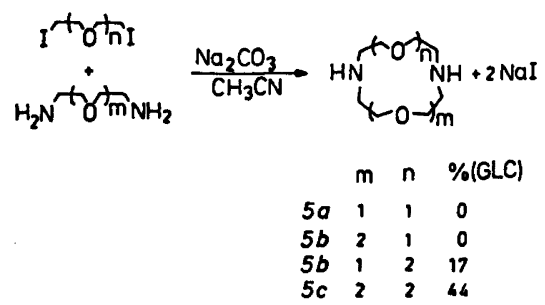

Scheme 2.

In Scheme 2 the intermediates are ammonium ions unlikely to form complexes with any positively charged ion, and therefore the presence of a base is necessary. Alkali metal carbonates are non-nucleophilic bases, which furthermore provide the solution with the template ion after reaction with the ammonium salt formed (Scheme 2). Unfortunately, the carbonates are insoluble in organic solvents and therefore the acid-base reaction must be a two-phase reaction. ${ }^{27}$

If a template effect exists, one would expect a variation of the macrocycle yield with different alkali cations. As can be seen in Table 1 this is also the case, but the most favourable ion is not the same in the different solvents. The yields are not correlated with the solubilities of the alkali metal iodides formed (Scheme 2). Still the solvent is of great importance, since the complex formation between the ring precursor intermediate and the template ion is disfavoured by strong solvation of the template ion. ${ }^{28}$ The mechanism will be discussed in more detail in a future publication..$^{18}$

In the protic solvent methanol the yield is very low compared to those in the aprotic solvents glyme and dioxane. In acetonitrile, which does not solvate alkali metal ions so strongly,,$^{28}$ the yields are higher with a maximum for the sodium ion, and hence this system was chosen for the synthetic procedure.

Table 1. The yields (\%) of $5 c$, determined by GLC, in different solvents and with different alkali metal carbonates.

\begin{tabular}{lllll}
\hline Solvent & \multicolumn{2}{c}{ Template ion } \\
$\mathrm{Li}^{+}$ & $\mathrm{Na}^{+}$ & $\mathrm{K}^{+}$ & $\mathrm{Cs}^{+}$ \\
\hline Acetonitrile & 6 & 44 & 27 & 15 \\
Dioxane & & 16 & 24 & \\
Glyme & & 8 & 24 & 15 \\
Methanol & & & $<5$ & \\
\hline
\end{tabular}

Acta Chem. Scand. B 33 (1979) No. 7 
However, the template effect. of the sodium ion is not very strong in the formation of the smaller rings. With iodide $2 a$ this effect cannot compete with the more favourable formation of six-membered rings (Scheme 3), and the reaction gives morpholine derivatives exclusively.

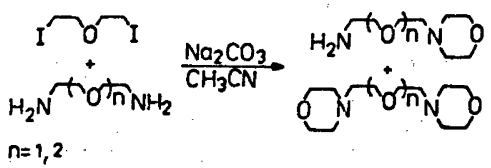

Scheme 3.

$\mathrm{N}, \mathrm{N}^{\prime}$-Disubstituted macrocycles. The macrocycle $5 c$ was provided with "arms" (Scheme 4) in order to get compounds with specific complexing properties toward certain metal ions. The reactions all appear simple, but certain difficulties are involved.

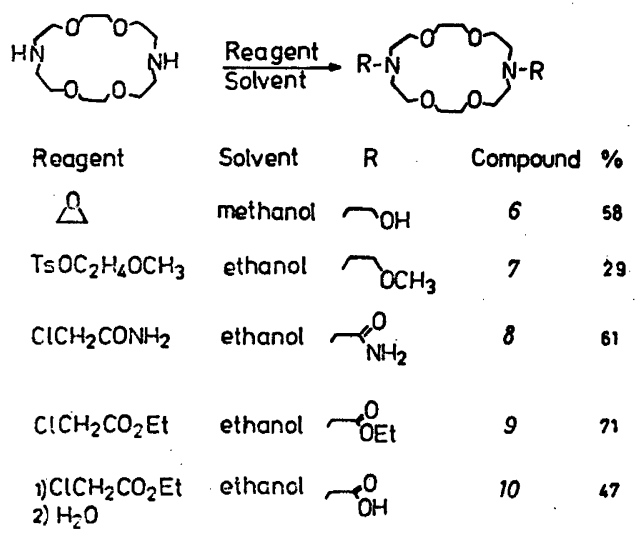

Scheme 4.

In the synthesis of 6, a moderate excess of ethylene oxide was necessary in order to avoid monosubstituted byproducts, whereas too high an excess gave compounds with more than one ethylene oxide unit in the side-chains. Distillation gave a rather good, albeit not complete, separation of 6 from these products.

In the synthesis of 7 , excess tosylate resulted in degradation, probably due to elimination of quaternary ammonium ions formed.

The formation of 8 and 9 is fast and clean, but the subsequent hydrolysis offers a problem: The amino acid 10 does not precipitate in water at its isoelectric point, and is therefore difficult to separate from other components. Fortunately, 9 is readily hydrolyzed in pure water without a catalyst, and in dilute ethanol 10 precipitates with two water molecules. These are removed by warming at reduced pressure.

Toxicity. The polyheteroatom macrocycles can all be suspected to possess biological activity due to their special complexing abilities. ${ }^{29}$ Very little has been published about their toxicology, ${ }^{1,30}$ however. Preliminary toxicolog. ical data for some of the disubstituted diazacrown ethers are given in Table 2. The $\mathrm{LD}_{50}$ value for $4,7,13,16,21,24$-hexaoxa-1,10-diazabicyclo-[8,8,8]-hexacosan (Kryptofix 222) is 32 $\mathrm{mg} \mathrm{kg-1}$ (i.v. mouse), ${ }^{27}$ and the values for 6 and 10 are similar, while the values for $5 c$ and 8 are a little smaller. This does not indicate any dramatic toxicity of this class of compounds, and the symptoms seem to be reversible ${ }^{30}$ without any visible effects after a week.

\section{EXPERIMENTAL}

The solvents, the sodium iodide and the alkali metal carbonates were of analytical grade, while the other reagents used in this work were of reagent grade.

Methoxyethyl p-toluenesulfonate, b.p. 135$137^{\circ} \mathrm{C} / 0.2 \mathrm{mmHg}$, was prepared according to known methods..$^{31}$ The starting material,bis. (2-chloroethyl) ether (1a), was purchased from Merck-Schuchardt AG, and 1,2-bis(2-chloroethoxy) ethane (1b) from Eastman Kodak Co.

IR spectra were recorded on a Perkin Elmer 257 instrument and ${ }^{1} \mathrm{H}$ NMR spectra on Varian A60 or JEOL JNM-MH-100 instruments. GLC analyses were performed using a HewlettPackard 5830A system with a $2 \mathrm{~m} \times 3 \mathrm{~mm} 3 \%$ OV 101 on Chromosorb W column. Mass spectral data were obtained using an LKB 9000 mass

Table 2. Toxicity tests on mice (weight approx. $20 \mathrm{~g}$ ) The number of individuals in each experiment is two and the route of administration i.v. injection.

\begin{tabular}{|c|c|c|c|}
\hline $\begin{array}{l}\text { Crown } \\
\text { ether }\end{array}$ & $\begin{array}{l}\text { Dose } \\
\mathrm{mg} / \mathrm{kg}\end{array}$ & $\begin{array}{l}\text { Survival after } \\
24 \mathrm{~h}\end{array}$ & 7 days \\
\hline $5 c$ & $\mathbf{5}$ & 2 & 2 \\
\hline 6 & $\begin{array}{l}25 \\
50\end{array}$ & $\begin{array}{l}\mathbf{2} \\
\mathbf{0}\end{array}$ & 2 \\
\hline 8 & $\begin{array}{r}5 \\
25\end{array}$ & $\begin{array}{l}\mathbf{2} \\
\mathbf{0}\end{array}$ & 2 \\
\hline 10 & $\begin{array}{l}25 \\
50\end{array}$ & $\begin{array}{l}\mathbf{2} \\
\mathbf{0} \\
\end{array}$ & 2 \\
\hline
\end{tabular}


spectrometer. Melting points were determined on a Kofler Heizbank. Elemental analyses were carried out at the Department of Analytical Chemistry, University of Lund.

Bis (2-iodoethyl) ether (2a). The synthesis has previously been described by Gibson and Johnson ${ }^{10}$ and was here carried out by the following modified procedure. A mixture of $1 a(143 \mathrm{~g})$ and sodium iodide $(375 \mathrm{~g})$ in acetone $(500 \mathrm{ml})$ was refluxed for $70 \mathrm{~h}$ and then filtered. The filtrate was evaporated and the residue, dissolved in ether, was washed with a water solution of sodium thiosulfate to remove iodine. The ether phase was evaporated and the crude product was distilled at reduced pressure, which gave $2 a$, yield $304 \mathrm{~g}(93 \%)$. The physical data agree with those found by others. ${ }^{16}$

1,2-Bis (2-iodoethoxy)ethane (2b). $16(190 \mathrm{~g})$ and sodium iodide $(330 \mathrm{~g})$ in acetone $(500 \mathrm{ml})$ were treated as in the previous synthesis. Yield $359 \mathrm{~g}(96 \%)$, b.p. $126-129^{\circ} \mathrm{C} / 0.5 \mathrm{mmHg}$, $n_{\mathrm{D}}{ }^{22}=1.5677$. GLC shows the presence of $>99 \%$ of 2b. Anal. $\mathrm{C}_{6} \mathrm{H}_{12} \mathrm{I}_{2} \mathrm{O}_{2}: \mathrm{C}, \mathrm{H}, \mathrm{O}$. NMR (CDCl ${ }_{3}$ ): $\delta 3.27(4 \mathrm{H}, \mathrm{t}), \delta 3.67(4 \mathrm{H}, \mathrm{s}), \delta 3.79(4 \mathrm{H}, \mathrm{t})$. MS [IP $70 \mathrm{eV;} m / e$ (\% rel. int.)]: $370(0.5, \mathrm{M})$, 243 (1, M-I), $215\left(4, M-C_{2} H_{4} I\right), 199$ (20, M$\left.\mathrm{OC}_{2} \mathrm{H}_{4} \mathrm{I}\right), 155\left(100, \mathrm{C}_{2} \mathrm{H}_{4} \mathrm{I}\right)$.

1,2-Bis (2-azidoethoxy) ethane (3b). $16(300 \mathrm{~g})$ was added dropwise to a stirred solution of sodium azide $(230 \mathrm{~g})$ in DMSO (1000 $\mathrm{ml})$ and the temperature was kept at $90^{\circ} \mathrm{C}$ for $4 \mathrm{~h}$. The mixture was then poured into $1500 \mathrm{ml}$ of ice-water and extracted with ether. The ether phase was thoroughly washed with water and then evaporated, which gave $3 b$, yield $311 \mathrm{~g}$ (97\%). The physical data agree with those found by others. ${ }^{21}$

Bis(2-aminoethyl) ether (4a). Sodium azide $(135 \mathrm{~g})$ was added to a stirred solution of $1 a$ $(143 \mathrm{~g})$ in DMSO $(500 \mathrm{ml})$ and the temperature was kept at $90^{\circ} \mathrm{C}$ for $4 \mathrm{~h}$. Then the mixture was poured into $750 \mathrm{ml}$ of ice-water and extracted with ether. The ether phase, thoroughly washed with water, was evaporated, and the residue (crude $3 a$ ) was dissolved in ethanol $(200 \mathrm{ml})$. Triethylamine $(10 \mathrm{ml})$ was added and hydrogen sulfide was bubbled through the boiling solution for $18 \mathrm{~h}$. After cooling, concentrated hydrochlo. ric acid was slowly added and the precipitated sulfur was filtered off. Sodium hydroxide ( $100 \mathrm{~g}$ ) was added with cooling and the solution was continuously extracted for $24 \mathrm{~h}$ with chloroform, which was then distilled off. The residue was distilled under reduced pressure, which gave $4 a$ as a hygroscopic liquid, yield $68 \mathrm{~g}$ (65 \%). The physical data agreed with those found by others. ${ }^{3}$

1,2-(2-Aminoethoxy)ethane (4b). Hydrogen sulfide was bubbled through a boiling solution of $3 b(194 \mathrm{~g})$ and triethylamine $(10 \mathrm{ml})$ in ethanol $(200 \mathrm{ml})$ for $18 \mathrm{~h}$. The solution was treated as in the previous synthesis and then extracted continuously for $48 \mathrm{~h}$ with chloroform, which was then evaporated. Distillation of the residue at reduced pressure gave $4 b$ as a hygroscopic liquid, yield $126 \mathrm{~g}$ (88 \%). The physical data agreed with those found by others. ${ }^{3}$

\section{1,7,10,16-Tetraoxa-4,13-diazacyclooctadecane}

(5c). A solution of $4 b(33 \mathrm{~g})$ in acetonitrile $(100 \mathrm{ml})$ was added over a period of $3 \mathrm{~h}$ to a boiling solution of $2 b$ in acetonitrile $(400 \mathrm{ml})$ over finely ground sodium carbonate (125 g), after which the mixture was refluxed for $18 \mathrm{~h}$. Filtration and evaporation of the filtrate gave a residue, which was dissolved in a boiling mixture of dioxane $(50 \mathrm{ml})$ and acetone $(50 \mathrm{ml})$. After cooling and standing overnight, white crystals were precipitated. These crystals (94 g), probably the sodium iodide complex of $5 c$ wit.' dioxane attached to it, were filtered off and dissolved in water, and the solution was continuously extracted with chloroform for $18 \mathrm{~h}$. Evaporation of the chloroform gave a crude product, which was recrystallized in heptane giving $5 c$, yield $15.5 \mathrm{~g}(30 \%)$. The physical data agreed with those found by others. ${ }^{3}$

$\mathrm{N}, \mathrm{N}^{\prime}$-Bis-(2-hydroxyethyl) $-1,7,10,16$-tetraoxa . 4,13-diazacyclooctadecane (6). Ethylene oxide $(5 \mathrm{ml})$ at $0{ }^{\circ} \mathrm{C}$ was added to a solution of $5 c$ $(6.6 \mathrm{~g})$ in methanol $(40 \mathrm{ml})$ on an ice-bath, after which it was refluxed first for $2 \mathrm{~h}$ with a condenser chilled with ice and then for $1 \mathrm{~h}$ with an ordinary condenser. The methanol was evaporated and the residue was distilled at reduced pressure, which gave 6 , yield $5.1 \mathrm{~g}$ (58 \%), b.p. $210-214^{\circ} \mathrm{C} / 0.15 \mathrm{mmHg}, n_{\mathrm{D}}{ }^{23}=$ 1.4929. GJ,C showed the presence of $98 \%$ of 6 . Anal. $\mathrm{C}_{16} \mathrm{H}_{34} \mathrm{~N}_{2} \mathrm{O}_{8}: \mathrm{C}, \mathrm{H}, \mathrm{N}, \mathrm{O}$. NMR (CDCl 3 ): $\delta 2.67, \delta 2.77(12 \mathrm{H}, \mathrm{t}, \mathrm{t}), \delta 3.65(22 \mathrm{H}, \mathrm{s}, \mathrm{m})$. MS [IP $70 \mathrm{eV} ; m / e(\%$ rel. int.)]: $350(1, \mathrm{M})$, 349 (1), 333 (1, M-OH), 319 (100, M- $\left.\mathrm{CH}_{2} \mathrm{OH}\right)$, 289 (23), $275(20), 188(10), 176(10), 162(25)$, 146 (20), 144 (25), 132 (18), 114 (35), $100(40)$. IR (film): 3270 (s, broad, OH).

$\mathrm{N}, \mathrm{N}^{\prime}$-Bis (2-methoxyethyl)-1,7,10,16-tetraoxa4,13-diazacyclooctadecane (7). A solution of $5 c$ $(7.9 \mathrm{~g})$, methoxyethyl $p$-toluene sulfonate $(15.6 \mathrm{~g})$ and triethylamine $(6.6 \mathrm{~g})$ in ethanol $(50 \mathrm{ml})$ was refluxed for $5 \mathrm{~h}$ and then the ethanol was evaporated. The residue was dissolved in water and extracted with ether. Triethylamine was added to the water phase, which was then extracted with chloroform. The chloroform was evaporated and the residue distilled at reduced pressure, which gave 7 , yield $3.2 \mathrm{~g}(29 \%)$, b.p. $197-199{ }^{\circ} \mathrm{C} / 0.1 \mathrm{mmHg}, n_{\mathrm{D}}^{22}=1.4748$. GLC showed the presence of $99 \%$ of $\%$. Found: C 55.6; $\mathrm{H}$ 10.2; $\mathrm{N}$ 7.47. Calc. for $\mathrm{C}_{18} \mathrm{H}_{38} \mathrm{~N}_{2} \mathrm{O}_{6}$ : C 57.1; H 10.1; N 7.40. NMR $\left(\mathrm{CDCl}_{3}\right): \delta 2.74$, $\delta 2.84(12 \mathrm{H}, \mathrm{t}, \mathrm{t}), \delta 3.34(6 \mathrm{H}, \mathrm{s}), \delta 3.46(4 \mathrm{H}, \mathrm{t})$, $\delta 3.61(16 \mathrm{H}, \mathrm{t}, \mathrm{s})$. MS [(IP $70 \mathrm{eV} ; \mathrm{m} / \mathrm{e} / \% \mathrm{rel}$. int.)]: $378(5, M), 377(3), 376(2), 347$ (10, $\left.\mathrm{M}-\mathrm{OCH}_{3}\right), 333\left(100, \mathrm{M}-\mathrm{CH}_{2} \mathrm{OCH}_{3}\right), 303(6)$, 176 (15), $146(10), 144$ (23), $116(10), 114(20)$, 102 (15), 100 (22).

$\mathrm{N}, \mathrm{N}^{\prime}$-Bis(carbamoylmethyl)-1,7,10,16-tetraoxa4,13-diazacyclooctadecane (8), A solution of $5 \mathrm{c}(5.2 \mathrm{~g})$, chloroacetamide $(4.1 \mathrm{~g})$ and triethylamine $(5 \mathrm{~g})$ in ethanol $(25 \mathrm{ml})$ was refluxed for $3 \mathrm{~h}$. The solution was allowed to 
cool and white crystals precipitated. The crystals $(6 \mathrm{~g})$ were filtered off and recrystallized from $90 \%$ ethanol, which gave 8 , yield $4.6 \mathrm{~g}$ $(61 \%)$, m.p. $161^{\circ} \mathrm{C}$. Anal. $\mathrm{C}_{16} \mathrm{H}_{32} \mathrm{~N}_{4} \mathrm{O}_{6}: \mathrm{C}, \mathrm{H}, \mathrm{N}$. NMR $\left(\mathrm{CDCl}_{3}\right): \delta 2.74(8 \mathrm{H}, \mathrm{t}), \delta 3.14(4 \mathrm{H}, \mathrm{s})$, $\delta 3.54(8 \mathrm{H}, \mathrm{t}), \delta 3.61(8 \mathrm{H}, \mathrm{s})$. MS [IP $70 \mathrm{eV}$; $m / e$ (\% rel. int.)]: $377(2, M+H), 376(8, M)$, 332 (100, M.CONH ${ }_{2}$ ), 315 (8), 286 (8), 275 (5), 175 (10), $173(8), 158(7), 146(10), 144(32)$, 114 (15), 101 (15), 100 (30). IR (KBr): 3360, $3180\left(\mathrm{~s}, \mathrm{NH}_{2}\right), 1690,1660(\mathrm{~s}, \mathrm{CO})$.

$\mathrm{N}, \mathrm{N}^{\prime} \cdot$-Bis(ethoxycarbonylmethyl) $-1,7,10,16$.

tetraoxa-4,7-diazacyclooctadecane (9). A solution of $5 c(2.6 \mathrm{~g})$, ethyl chloroacetate $(2.7 \mathrm{~g})$ and trimethylamine $(4 \mathrm{~g})$ in ethanol $(20 \mathrm{ml})$, was refluxed for $18 \mathrm{~h}$, after which it was poured into water and extracted with chloroform. The chloroform was evaporated and the residue was distilled at reduced pressure, which gave 9 , yield $3.1 \mathrm{~g}(71 \%)$, b.p. $218-220^{\circ} \mathrm{C} / 0.2 \mathrm{mmHg}$, $n_{\mathrm{D}}{ }^{22}=1.4770$. GLC showed the presence of $>99 \%$ of 9 . Found: C 54.7 ; H 8.88; N 6.12; O 29.9. Calc. for $\mathrm{C}_{20} \mathrm{H}_{38} \mathrm{~N}_{2} \mathrm{O}_{8}$ : C 55.3; $\mathrm{H}$ 8.83; $\mathrm{N} 6.45 ; \mathrm{O} 29.5$. NMR $\left(\mathrm{CDCl}_{3}\right): \delta 1.26(6 \mathrm{H}, \mathrm{t})$, $\delta 2.96(8 \mathrm{H}, \mathrm{t}), \delta 3.52(4 \mathrm{H}, \mathrm{s}), \delta 3.62(16 \mathrm{H}, \mathrm{t}, \mathrm{s})$, $\delta 4.16(4 \mathrm{H}, \mathrm{q})$. MS [IP $70 \mathrm{eV} ; m / e$ (\% rel. int.)]: $435(5, M+H), 434(20, M), 373(15), 361$ (100, $\left.\mathrm{M}-\mathrm{CO}_{2} \mathrm{C}_{2} \mathrm{H}_{3}\right), 204 \quad(25), 202$ (10), 144 (32), $130(30), 116(12), 114(30), 100$ (25). IR (film): 1740 (s, CO).

$\mathrm{N}, \mathrm{N}^{\prime}-$ Bis (carboxymethyl)-1,7,10,16-tetraoxa-4,7diazacyclooctadecane (10). A solution of $5 c(2.6 \mathrm{~g})$, ethyl chloroacetate $(2.7 \mathrm{~g})$ and triethylamine $(4 \mathrm{~g})$ in ethanol $(20 \mathrm{ml})$ was refluxed for $24 \mathrm{~h}$ and then poured into water and extracted with chloroform. The chloroform was evap. orated and the residue $(4.2 \mathrm{~g})$ was dissolved in water $(25 \mathrm{ml})$ and refluxed for $18 \mathrm{~h}$. The water was evaporated and the residue was recrystallized in $80 \%$ ethanol. White crystals were obtained, which were dried at $60^{\circ} \mathrm{C} / 0.02$ $\mathrm{mmHg}$ to remove water of crystallization, which gave 10, yield $1.8 \mathrm{~g}(47 \%)$, m.p. $171-173^{\circ} \mathrm{C}$. Anal. $\mathrm{C}_{10} \mathrm{H}_{30} \mathrm{~N}_{2} \mathrm{O}_{8}: \mathrm{C}, \mathrm{H}, \mathrm{N}$, O. NMR $\left(\mathrm{D}_{2} \mathrm{O}\right): \delta 4.05$ $(8 \mathrm{H}, \mathrm{t}), \delta 4.22(8 \mathrm{H}, \mathrm{s}), \delta 4.34(12 \mathrm{H}, \mathrm{s}, \mathrm{t})$. MS [IP $70 \mathrm{eV} ; m / e(\%$ rel. int.)]: $378(1, \mathrm{M})$, $334\left(8, \mathrm{M}-\mathrm{CO}_{2}\right), 289\left(25,\left(\mathrm{M}-\mathrm{CO}_{2}\right)-\mathrm{CO}_{2} \mathrm{H}\right)$, $275\left(5,\left(\mathrm{M}-\mathrm{CO}_{2}\right)-\mathrm{CH}_{2} \mathrm{CO}_{2} \mathrm{H}\right), 229(25), 215$ (32), 206 (10), 190 (15), 187 (12), 158 (22), $146(72), 145(22), 144(32), 132(45), 130(25)$, 116 (32), $115(30), 114(42), 102$ (55), $101(30)$, $100(100)$. IR (KBr): $3400(\mathrm{~m}), 2100-2400$ (s, broad), 1640 (s, CO).

Ring-closure reaction in different solvents and with different alkali metal carbonates. $2 b$ (10 $\mathrm{mmol}$ ) was added dropwise to a boiling solution of $4 b \quad(10 \mathrm{mmol})$ in $25 \mathrm{ml}$ of the solvent over $60 \mathrm{mmol}$ finely ground alkali metal carbonate. The mixture was refluxed for $3 \mathrm{~h}$ and then filtered. The GLC analyses were performed on a diluted sample of the filtrate.

Acknowledgements. We thank Prof. Lennart Eberson for valuable discussions and we are grateful to the Swedish Natural Science Research Council (via L.E.) and to the Royal
Physiographic Society of Lund for financial support. We also wish to thank Draco AB, Lund, for performing the toxicity tests.

\section{REFERENCES}

1. Pedersen, C. J. J. Am. Chem. Soc. 89 (1967) 7017.

2. Dietrich, B., Lehn, J.-M. and Sauvage, J. P. Tetrahedron Lett. (1969) 2885.

3. Dietrich, B., Lehn, J.-M. and Sauvage, J. P. Tetrahedron 29 (1973) 1629.

4. Frensdorff, H. K. J. Am. Chem. Soc. 93 (1971) 600 .

5. Lehn, J.-M. and Sauvage, J. P. Chem. Commun. (1971) 440.

6. Cram, D. J., Helgeson, R. C., Koga, K., Kyba, E. P., Madan, K., Sonsen, L. R., Siegel, M. G., Moreau, P., Gokel, G. W., Timko, J. M. and Sogah, G. D. Y. J. Org. Chem. 43 (1978) 2758.

7. Timko, J. M., Helgeson, R. C. and Cram, D. J. J. Am. Chem. Soc. 100 (1978) 2828.

8. Kappenstein, C. Bull. Soc. Chim. Fr. (1974) 89.

9. Cram, D. J. and Cram, J. M. Science 183 (1974) 803.

10. Gokel, G. W. and Durst, H. D. Synthesis (1976) 168.

11. Lehn, J.-M. Acc. Chem. Res. 11 (1978) 49.

12. Arnaud-Neu, F., Speiss, B. and SchwingWeil, M. J. Helv. Chim. Acta 60 (1977) 2633.

13. Lehn, J.-M. and Montavon, F. Helv. Chim. Acta 61 (1978) 67.

14. Lehn, J.-M. and Sauvage,jJ. P. J. Am. Chem. Soc. 97 (1975) 6700.

15. Richman, J. E. and Atkins, T. J. J. Am. Chem. Soc. 96 (1974) 2268.

16. Russhofer, W., Wehner, W. and Vögtle, F. Justus Liebigs Ann. Chem. (1976) 916.

17. Cook, F. L., Caruso, T. C., Byrne, M. P., Bower, C. W., Speck, D. H. and Liotta, C. L. Tetrahedron Lett. (1974) 4029.

18. Kulstad, S. and Malmsten, L.-A. To be published.

19. Gibson, C. S. and Johnson, J. D. A. J. Chem. Soc. (1930) 2525.

20. Dwyer, F. P., Gill, N. S., Gyarfas, E. C. and Lions, F. J. Am. Chem. Soc. 75 (1953) 1526.

21. Durden, J. A., Stausburg, H. A. and Catlette, W. A. J. Chem. Eng. Data 9 (1964) 228.

22. Desreux, J. F., Renard, A. and Duyckerts, G. J. Inorg. Nucl. Chem. 39 (1977) 1587.

23. Gronowitz, S., Westerlund, C. and Hörnfeldt, A.-B. Acta Chem. Scand. B 29 (1975) 224.

24. Greene, R. N. Tetrahedron Lett. (1972) 1793.

25. Dale, J. and Kristiansen, P. O. Acta Chem. Scand. $B 26$ (1972) 1479.

26. Lockhart, J. C., Robson, A. C., Thompson, M. E., Furtado, S. D., Kaura, C. K. and Allan, A. R. J. Chem. Soc. Perkin Trans. 1 (1973) 577. 
27. Fedoryński, M. Wojcieckowski, K., Matacz, Z. and Makosza, M. J. Org. Chem. 43 (1978) 4682.

28. Kulstad, S. and Malmsten, L. A. To be published.

29. Leong, B. K. J., Ts'O, T. O. T. and Chenoweth, M. B. Toxicol. Appl. Pharmacol. 27 (1974) 342.

30. Baudot, P., Jacque, M. and Robin, M. Toxicol. Appl. Pharmacol. 41 (1977) 113.

31. Stuart-Tipson, R. J. Org. Chem. 9. (1944) 235.

Received March 28, 1979. 